\title{
Pengembangan E-marketplace In-game Currency Menggunakan Framework Laravel dengan Metode Extreme Programming
}

http://dx.doi.org/10.28932/jutisi.v7i2.3945

Riwayat Artikel

Received: 31 Agustus 2021 | Final Revision: 25 November 2021 | Accepted: 25 November 2021

\author{
Daniel Apdianto Herman ${ }^{\bowtie \# 1}$, Andy Kho*2 \\ \# Program Studi Sistem Informasi, Universitas Internasional Batam \\ Sei Ladi, Jl. Gajah Mada, Baloi Permai, Kec. Sekupang, Kota Batam, Kepulauan Riau 29442 \\ ${ }^{1}$ daniel.herman@uib.ac.id \\ "Program Studi Sistem Informasi, Universitas Internasional Batam \\ Sei Ladi, Jl. Gajah Mada, Baloi Permai, Kec. Sekupang, Kota Batam, Kepulauan Riau 29442 \\ 21831089. andy@uib.edu
}

\begin{abstract}
In-game currency can be used to purchase various in-game items, especially in online games. In addition, in-game currency is also widely traded by players in certain online games. This eventually causes the potential for scam in buying and selling in-game currency to increase. This happened because there is no place that can be used by players to do transactions safely. The purpose of this research is to design and develop an e-marketplace for in-game currency using the Extreme Programming method which consists of planning, design, coding, and testing stages. This in-game currency e-marketplace application will be developed using the Laravel framework, which is one of the open-source PHP frameworks. The result of this research is an e-marketplace application that can be used by in-game currency buyers or sellers to do buying and selling easily and safely. With this e-marketplace, buying and selling in-game currency transactions will be easier, faster, and also scam-free.
\end{abstract}

Keywords— digital goods; e-marketplace; in-game currency.

\section{PENDAhUluan}

Game online merupakan permainan yang dapat dimainkan oleh banyak orang secara online. Ada game online yang memiliki cerita dan tantangan yang menarik, ada yang melibatkan emosi, dan ada juga yang terasa seperti terlibat langsung di dalamnya [1]. Pada game online, terdapat virtual items yang hanya dapat digunakan di dalam game online tersebut. Virtual items ini disebut sebagai in-game items. Dengan kata lain, in-game items bergantung pada game online tertentu. Keberadaan in-game items juga memiliki batas waktu, tergantung apakah game online tersebut masih aktif atau tidak. Salah satu in-game items yang terdapat pada hampir setiap game online adalah in-game currency [2].

In-game currency dapat digunakan untuk membeli berbagai in-game items. Karena itu, transaksi jual beli in-game currency menjadi marak terjadi. Baik transaksi langsung dengan game online tersebut, maupun transaksi dengan pemain lainnya. Namun, tentu saja hal ini menyebabkan potensi terjadinya penipuan semakin meningkat [3]. Salah satu contohnya adalah pada game online Growtopia. Pada game online ini, sangat banyak pemain yang melakukan transaksi jual beli ingame currency. Hal ini dikarenakan in-game currency pada game online ini cukup mudah didapatkan dan harganya juga lumayan tinggi. Akibatnya, penipuan di game online ini marak terjadi. Salah satu contoh kasus penipuan game online ini terjadi di Singapura. Pada kasus tersebut, seorang remaja berumur 16 tahun ditangkap karena menipu pemain lainnya dalam hal transaksi in-game currency pada game online Growtopia [4].

Penelitian yang dilakukan oleh Tristiyanto, Yunda Heningtyas, dan Hanan Risnawati adalah salah satu penelitian yang menjadi dasar utama dari penelitian ini. Pada penelitian tersebut, dirancang dan dikembangkan sebuah e-marketplace penyewaan untuk koperasi dengan tujuan untuk mempertemukan penyewa dan pemilik barang sehingga transaksi penyewaan dapat dilakukan dengan lebih efektif. Menurutnya, proses penyewaan yang dilakukan secara konvensional sering kali menyulitkan penyewa karena penyewa harus mengunjungi pemilik barang secara langsung untuk mengetahui informasi mengenai barang yang ingin disewa. Metode yang digunakan dalam penelitian tersebut adalah metode Extreme 
Programming yang memiliki empat tahapan, yaitu planning, design, coding, dan testing. Pada akhir penelitian tersebut, berhasil dibangun sebuah $e$-marketplace penyewaan untuk koperasi di mana hasil yang didapatkan dari penelitian tersebut juga berhasil sesuai dengan yang diinginkan. Berdasarkan penelitian tersebut, didapatkan referensi mengenai metode dan cara perancangan serta pengembangan sebuah $e$-marketplace [5].

Penelitian lainnya adalah penelitian yang dilakukan oleh Erwin Yulianto dan Fajar Nurochim. Menurut penelitian tersebut, potensi ekonomi dari peluang usaha barang digital sangatlah tinggi, namun hanya sedikit masyarakat Indonesia yang sudah mengetahui hal tersebut. Karena itulah dalam penelitian tersebut, dibangun sebuah $e$-marketplace barang digital yang dapat mempermudah masyarakat, khususnya para talenta digital di Indonesia dalam mencari, menjual, maupun membeli produk-produk digital. Metode dalam penelitian tersebut dilakukan dengan menggunakan pendekatan Case Study Research. Kemudian, penelitian tersebut menggunakan metode Software Development Life Cycle untuk mengembangkan aplikasi e-marketplace barang digital tersebut, yaitu dimulai dengan pemetaan kebutuhan pengguna, lalu berlanjut ke tahapan perencanaan, pemodelan, konstruksi, dan penyerahan sistem ke pengguna. Pada akhir penelitian tersebut, berhasil dikembangkan sebuah $e$-marketplace barang digital yang mampu mempertemukan penjual dan pembeli barang digital serta mengkampanyekan barang digital di Indonesia sebagai peluang usaha baru yang potensial sesuai dengan tujuan dari penelitian tersebut. Berdasarkan penelitian tersebut, didapatkan referensi mengenai potensi dari usaha jual beli barang digital, terutama di Indonesia [6].

E-marketplace adalah salah satu sarana untuk mewadahi penjual dan pembeli dalam melakukan transaksi jual beli secara online. Alasan mengapa orang-orang lebih memilih untuk menggunakan e-marketplace dalam bertransaksi, antara lain bisa berkomunikasi secara langsung, adanya rekening bersama, dan juga transaksi yang lebih aman. Dengan memanfaatkan $e$ marketplace, penjual dan pembeli akan sangat terbantu. Hal ini dikarenakan tidak adanya batasan jarak dan waktu untuk saling berinteraksi dan bertransaksi [7]. Setiap e-marketplace memiliki bidangnya masing-masing. Kebanyakan dari emarketplace yang sudah ada saat ini bergerak di bidang komoditi barang fisik. Namun seiring berjalannya waktu, kebutuhan akan barang non-fisik semakin meningkat, terutama barang digital seperti in-game currency [6].

Untuk merancang dan membangun aplikasi e-marketplace in-game currency ini, digunakan framework Laravel dengan metode Extreme Programming. Framework Laravel adalah framework PHP open-source yang menerapkan konsep MVC (Model, View, \& Controller) yang banyak digunakan untuk mengembangkan aplikasi berbasis web. Framework Laravel pertama kali dikembangkan oleh Taylor Otwell pada tahun 2012.

Model MVC yang terdapat pada framework Laravel merupakan model pengembangan dengan memisahkan model atau data, view atau tampilan, dan controller atau pemroses. Model berperan untuk menghubungkan controller dengan database. Seluruh query yang ingin dilakukan akan diatur oleh model untuk kemudian dikirimkan ke database. View berperan untuk menampilkan data sesuai dengan yang diinginkan. View adalah bagian yang berinteraksi langsung kepada pengguna. Dan controller berperan untuk menghubungkan antara model dengan view, di mana fungsi dari controller adalah memproses perintah yang telah dibuat untuk menentukan proses berjalannya aplikasi. Dengan menggunakan framework Laravel, komponen pemrograman dapat menjadi reusable. Standar penulisan kode program pada framework Laravel juga wajib diikuti oleh setiap orang yang ada dalam tim, sehingga akan mempermudah dan mempercepat pengembangan aplikasi. Di samping itu, framework Laravel juga dapat memberikan keamanan dari serangan eksternal [8].

Selanjutnya, metode Extreme Programming adalah metode pengembangan perangkat lunak yang dapat mempercepat pembangunan suatu sistem, menyederhanakan tahapan pengembangan, dan mengutamakan fleksibilitas terhadap perubahan yang terjadi. Extreme Programming memiliki empat tahapan, yaitu planning, design, coding, dan testing [9]. Fakta bahwa metode ini disebut sebagai "Extreme Programming" juga merupakan keunggulan lain dari metode Extreme Programming ini, di mana metode ini merupakan metode ekstrim yang sangat membantu dalam mengembangkan aplikasi berkualitas tinggi dengan tingkat kepuasan konsumen yang tinggi, umpan balik yang cepat, dan biaya produksi yang lebih rendah. Selain hal tersebut, metode Extreme Programming juga menerapkan sistem pair programming yang dapat mempercepat dan meminimalisir terjadinya kesalahan dalam proses pengembangan aplikasi. Berikutnya, metode Extreme Programming juga memiliki lima nilai yang difokuskan, yaitu simplicity, communication, feedback, courage, dan respect [10]. Dengan menerapkan pair programming dan kelima nilai dalam metode Extreme Programming, maka proses pengembangan aplikasi akan menjadi jauh lebih cepat, efisien, dan berkualitas.

Berdasarkan latar belakang tersebut, maka akan dilakukan perancangan dan dikembangkan sebuah aplikasi $e$ marketplace untuk in-game currency berbasis website, yang dapat mempermudah proses transaksi antara penjual dan pembeli, terutama dalam hal transaksi in-game currency. E-marketplace ini akan memiliki beberapa fitur, seperti market dan wallet, serta dilengkapi juga dengan panel admin yang akan membantu proses yang berjalan pada $e$-marketplace ini.

\section{MetOde PENELITIAN}

Perancangan dan pengembangan aplikasi ini menggunakan metode Extreme Programming. Extreme Programming dikembangkan oleh Kent Beck pada tahun 1996 saat sedang mengembangkan aplikasi penggajian. Dalam bukunya yang berjudul "Extreme Programming Explained", dijelaskan bahwa metode Extreme Programming merupakan sebuah metode 
yang sangat ringan, fleksibel, dan memiliki resiko yang rendah, serta memiliki kemampuan untuk mengubah kebutuhan dari sistem dengan cepat [10].

Menurut Irmawati Carolina dan Adi Supriyatna, Extreme Programming (XP) merupakan sebuah proses rekayasa perangkat lunak yang cenderung menggunakan pendekatan berorientasi objek dan sasaran dari metode ini adalah tim yang dibentuk dalam skala kecil sampai medium serta metode ini juga sesuai jika tim dihadapkan dengan requirement yang tidak jelas maupun terjadi perubahan-perubahan requirement yang sangat cepat [11]. Dengan menggunakan metode Extreme Programming, proses perancangan dan pengembangan aplikasi ini akan menjadi lebih cepat dan mudah.

Metode Extreme Programming juga cocok digunakan untuk tim yang berukuran kecil hingga sedang. Selain itu, fakta bahwa metode ini disebut sebagai "Extreme Programming" juga merupakan keunggulan lain dari metode Extreme Programming ini, di mana metode ini merupakan metode ekstrim yang sangat membantu dalam mengembangkan aplikasi berkualitas tinggi dengan tingkat kepuasan konsumen yang tinggi, umpan balik yang cepat, dan biaya produksi yang lebih rendah [10].

Oleh karena itu, metode Extreme Programming dapat dikatakan cocok untuk digunakan pada perancangan dan pengembangan aplikasi e-marketplace ini, di mana untuk sekarang tim ini hanya beranggotakan dua orang. Selain itu, fleksibel terhadap perubahan-perubahan yang mungkin terjadi, juga dibutuhkan dalam perancangan dan pengembangan aplikasi yang sangat memungkinkan terjadinya perubahan-perubahan kebutuhan ini, baik secara mendadak ataupun tidak.

Pada metode Extreme Programming juga terdapat lima nilai yang difokuskan, yaitu simplicity, communication, feedback, courage, dan respect. Pada perancangan dan pengembangan aplikasi ini, simplicity dilakukan dengan tidak menambahkan fitur-fitur di luar kebutuhan pengguna. Selain itu, penggunaan framework dan package juga membantu dalam menyederhanakan penulisan code agar tidak banyak yang perlu dibuat secara manual. Metode Extreme Programming juga menekankan nilai communication pada pengguna. Pada pengembangan aplikasi ini, beberapa pengguna dan para pengembang akan bersama-sama akan melihat proses pengembangan dan memberikan saran secara langsung apabila ada yang terasa kurang, hal ini tentunya untuk mengurangi terjadinya ketidaksesuaian kebutuhan pengguna.

Selain communication, feedback dari pengguna juga penting, di mana pengguna akan melakukan pengujian secara langsung dan memberikan umpan balik mengenai aplikasi yang telah dikembangkan. Berikutnya, courage merupakan keberanian untuk mengambil keputusan dalam pengembangan aplikasi, contohnya seperti mengubah coding secara keseluruhan. Dan terakhir, respect merupakan sikap saling menghormati satu sama lain, baik pada pengguna maupun sesama tim.

Pada metode Extreme Programming, juga akan dilakukan iteration to release phase, yaitu sebuah metode di mana setiap tahapan dalam metode Extreme Programming, yaitu planning, design, coding, dan testing akan terus diiterasi atau diulangi berkali-kali hingga hasil akhir yang didapatkan sesuai dengan keinginan. Masing-masing iterasi memiliki aktivitas yang berbeda-beda, sesuai dengan iteration planning yang telah direncanakan. [10]. Model dari metode Extreme Programming dapat dilihat pada Gambar 1.

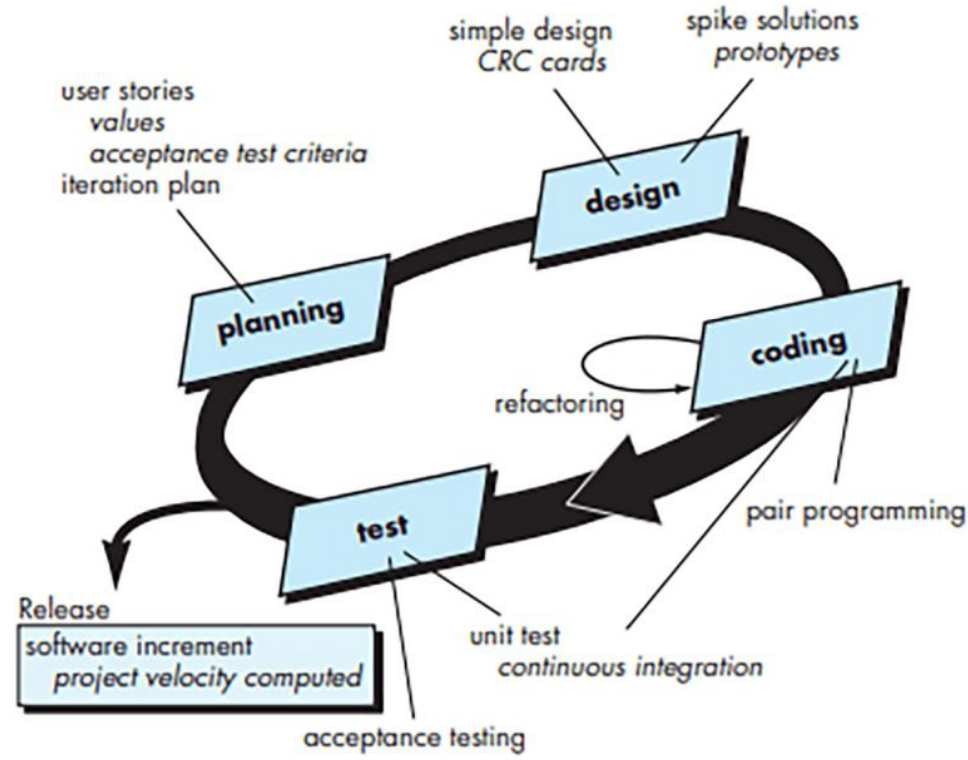

Gambar 1. Metode Extreme Programming [12] 
Berikut ini adalah tahapan dari metode Extreme Programming yang digunakan pada penelitian ini:

\section{A. Planning}

Tahapan planning dimulai dengan mengumpulkan kebutuhan pengguna, lalu membuat user stories yang akan menggambarkan output, fitur, dan fungsionalitas yang diperlukan. Pengguna akan memberikan nilai prioritas ke user stories berdasarkan tingkat kebutuhan dari fitur. User stories akan direpresentasikan dengan pemodelan diagram Unified Modeling Language yang terdiri dari Use Case Diagram, Activity Diagram, dan Entity Relationship Diagram. User stories akan digunakan sebagai dasar dari perancangan dan pengembangan aplikasi e-marketplace ini [13].

\section{B. Design}

Design merupakan tahapan kedua dari metode Extreme Programming. Pada tahapan ini, akan dilakukan perancangan desain diagram sistem, seperti use case diagram, activity diagram, serta entity relationship diagram dan desain antarmuka sistem berupa mockup berdasarkan user stories yang telah ada. Desain yang dirancang pada tahapan ini nantinya akan digunakan pada tahapan coding [11].

\section{Coding}

Selanjutnya, pada tahapan coding, aplikasi e-marketplace ini akan mulai dikembangkan. Pengembangan dilakukan dengan menerjemahkan desain diagram sistem dan mockup yang telah dirancang pada tahapan sebelumnya ke dalam bahasa pemrograman. Penulisan kode program pada penelitian ini dilakukan dengan menggunakan bahasa pemrograman PHP, dengan framework Laravel [5]. Proses pengkodean akan menggunakan text editor Visual Studio Code dengan internet browser Opera GX serta development server Laragon.

Pada tahapan coding, juga digunakan pair programming, yaitu cara pemrograman di mana dua programmer bekerja pada satu komputer yang sama. Dengan begitu, maka biaya produksi dapat ditekan serendah mungkin dan kualitas aplikasi yang dikembangkan dapat maksimal dikarenakan setiap error yang muncul dapat dengan mudah diketahui dan diperbaiki oleh programmer yang satunya [10].

Dengan menggunakan pair programming ini, pengembangan aplikasi dapat didampingi oleh pengguna secara langsung sehingga pengguna dapat terlibat langsung dalam pemrograman sambil berkomunikasi dengan pengembang aplikasi. Tujuan dari hal ini adalah untuk membuat pandangan dari pengembang aplikasi sesuai dengan pandangan dari pengguna sistem.

\section{Testing}

Terakhir, setelah proses coding selesai, akan dilakukan tahapan testing. Tahapan testing atau pengujian pada metode Extreme Programming berfokus pada keseluruhan fungsi dan fitur dari sistem yang dapat digunakan oleh pengguna berdasarkan user stories yang ada. Metode pengujian yang digunakan pada penelitian ini adalah metode Black-box Testing. Kemudian, metode Black-box Testing yang digunakan adalah metode Equivalence Partitioning, yaitu membagi masukan dari program ke dalam kelas-kelas terpisah sehingga dapat diperoleh kasus uji [14].

\section{HASIL DAN PEMBAHASAN}

Hasil dari penelitian ini berupa sebuah aplikasi e-marketplace in-game currency yang dirancang dan dikembangkan menggunakan framework Laravel dengan metode Extreme Programming. Aplikasi e-marketplace ini dapat mempermudah pelaku transaksi jual beli in-game currency dalam melakukan penjualan maupun pembelian in-game currency tertentu dengan mudah dan aman. Selain itu, terdapat juga fitur lainnya seperti wallet yang dapat digunakan untuk menyimpan atau mengirimkan in-game currency yang telah di-deposit-kan. Pengguna juga dapat melakukan withdraw terhadap in-game currency yang dimiliki ke akun game online masing-masing.

Pada perancangan dan pengembangan aplikasi e-marketplace in-game currency ini, proses iterasi yang dilakukan hanya sebatas iterasi pertama, karena selain untuk mempersingkat waktu, aplikasi ini sudah cukup baik dikembangkan untuk versi awalnya walau hanya dengan iterasi pertama. Selain itu, penggunaan framework Laravel dan berbagai package juga dilakukan untuk mempercepat proses pengembangan aplikasi ini. Berikut hasil perancangan dan pengembangan aplikasi serta hasil pengujian yang telah dilakukan berdasarkan metode Extreme Programming:

\section{A. Planning}

Pada tahapan planning, dilakukan analisis terhadap kebutuhan pengguna berdasarkan hasil wawancara dengan beberapa penjual maupun pembeli in-game currency yang ada di Facebook. Berdasarkan hasil wawancara tersebut, didapatkan berbagai informasi mengenai apa saja yang dibutuhkan oleh pengguna untuk e-marketplace in-game currency yang akan dikembangkan. Dari hasil wawancara tersebut, juga diketahui tingkat kebutuhan pengguna terhadap fitur berdasarkan user stories yang ada [13]. Pada Tabel 1 ditunjukkan beberapa user stories yang telah didapatkan. 
TABEL 1

USER STORIES

\begin{tabular}{ll}
\hline No. & Deskripsi \\
\hline $\mathbf{1}$ & $\begin{array}{l}\text { Sebagai pengguna, login atau register diperlukan sebelum menggunakan fitur-fitur di } e \text {-marketplace, sehingga data } \\
\text { pribadi, rupiah, serta in-game currency dapat terjamin aman. }\end{array}$ \\
\hline $\mathbf{2}$ & $\begin{array}{l}\text { Sebagai pengguna, ingin bisa melakukan pembelian dan penjualan in-game currency dengan mudah dan aman, } \\
\text { sehingga tidak perlu kesulitan dan takut tertipu. }\end{array}$ \\
\hline $\mathbf{3}$ & $\begin{array}{l}\text { Sebagai pengguna, ingin bisa melakukan pembelian dan penjualan in-game currency dengan harga tertentu, sehingga } \\
\text { bisa mendapatkan harga terbaik. }\end{array}$ \\
\hline $\mathbf{4}$ & $\begin{array}{l}\text { Sebagai pengguna, ingin bisa membeli dan menjual in-game currency dengan harga pasar, sehingga bisa dengan cepat } \\
\text { mendapatkan hasil pembelian atau penjualan. }\end{array}$ \\
\hline $\mathbf{5}$ & $\begin{array}{l}\text { Sebagai pengguna, ingin bisa mengirimkan in-game currency ke orang lain dengan mudah, sehingga tidak perlu repot- } \\
\text { repot harus online di dalam game terlebih dahulu. }\end{array}$
\end{tabular}

\section{B. Design}

Berikutnya, pada tahapan design, dilakukan pembuatan diagram-diagram sistem dalam bentuk use case diagram, activity diagram, serta entity relationship diagram dengan menggunakan draw.io dan desain antarmuka sistem dalam bentuk mockup dengan menggunakan Balsamiq Wireframes.

Pada tahapan ini, juga dilakukan komunikasi secara terus menerus dengan para pengguna mengenai desain sistem, baik itu diagram sistem maupun desain antarmuka sistem. Dengan begitu, didapatkan hasil desain yang cukup baik dan sesuai dengan kebutuhan dari pengguna. Pembuatan desain, baik mockup maupun diagram-diagram sistem ini juga dibuat agar mengacu pada user stories yang telah ditentukan sebelumnya [5].

1) Use Case Diagram: Use case diagram digambarkan dengan mengacu pada user stories yang telah dibuat sebelumnya. Dengan menggunakan use case diagram, dapat digambarkan apa saja yang dapat dilakukan oleh pengguna, baik pengguna biasa maupun admin dengan jelas. Admin dapat mengelola seluruh master data yang dibutuhkan pada aplikasi ini serta melakukan transaksi admin, seperti verifikasi deposit dan withdraw saldo wallet. Untuk melakukan hal tersebut, tentunya admin perlu melakukan login terlebih dahulu ke dalam panel admin yang telah disediakan. Selanjutnya, dari sisi pengguna, pengguna dapat melakukan berbagai macam bentuk transaksi, seperti deposit dan withdraw rupiah maupun in-game currency. Pengguna juga dapat membeli serta menjual ingame currency sesuai dengan market yang tersedia. Hasil dari penjualan maupun pembelian tersebut juga dapat ditarik atau di-withdraw sesuai dengan kebutuhan. Tentunya setelah melakukan deposit atau withdraw, admin harus memverifikasi deposit atau withdraw tersebut sebelum deposit atau withdraw tersebut dapat diproses. Untuk melakukan berbagai macam fitur transaksi yang disediakan tersebut, pengguna harus melakukan login terlebih dahulu ke dalam sistem, apabila pengguna tidak melakukan login, maka pengguna hanya dapat melihat informasiinformasi, seperti harga in-game currency, aktivitas market, dan grafik yang tersedia. Untuk lebih jelasnya, pada Gambar 2, ditunjukkan use case diagram dari aplikasi e-marketplace in-game currency ini. Sedangkan pada Tabel 2, ditunjukkan beberapa deskripsi singkat dari use case diagram pada Gambar 2 yang akan digunakan untuk pengujian nantinya. 


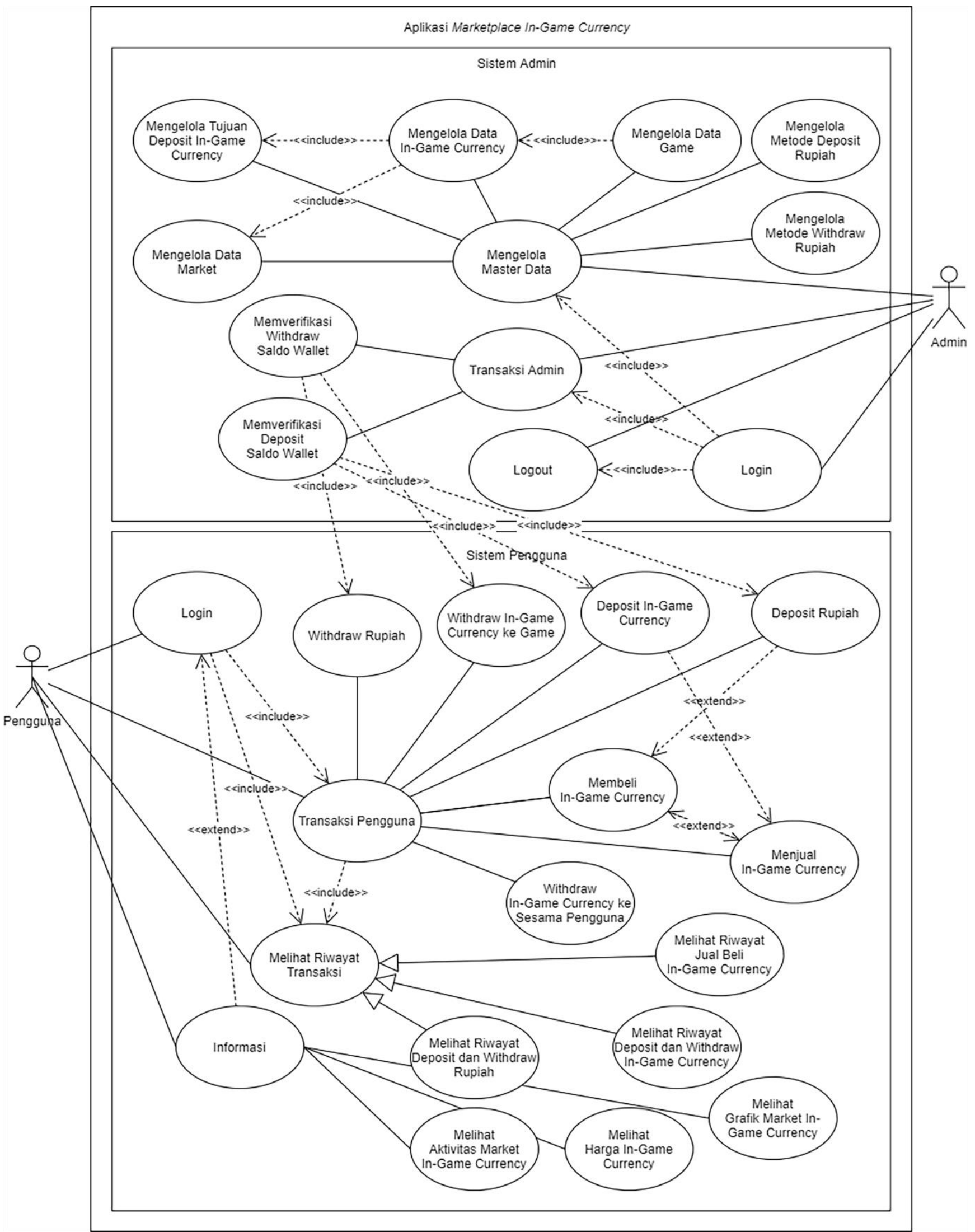

Gambar 2. Use Case Diagram 
TABEL 2

DESKRIPSI USE CASE

\begin{tabular}{|c|c|}
\hline Use Case & Deskripsi \\
\hline Register & $\begin{array}{l}\text { Mendaftarkan diri ke dalam e-marketplace dengan cara memasukkan data diri, seperti nama lengkap, } \\
\text { username, email, nomor handphone, dan password. }\end{array}$ \\
\hline Login & $\begin{array}{l}\text { Memasukkan username atau email dan password yang telah terdaftar untuk mendapat akses ke fitur yang } \\
\text { telah disediakan. }\end{array}$ \\
\hline $\begin{array}{l}\text { Deposit In-game } \\
\text { Currency }\end{array}$ & $\begin{array}{l}\text { Melakukan deposit in-game currency melalui game yang terkait agar dapat digunakan untuk dijual atau } \\
\text { dikirim lagi ke sesama pengguna. }\end{array}$ \\
\hline $\begin{array}{l}\text { Membeli In- } \\
\text { game Currency }\end{array}$ & $\begin{array}{l}\text { Melakukan pembelian in-game currency pada market yang telah disediakan. Pembelian dapat menggunakan } \\
\text { tipe limit, yaitu membeli dengan batas harga tertentu maupun market, yaitu membeli langsung dari pasar. }\end{array}$ \\
\hline
\end{tabular}

2) Activity Diagram: Activity diagram adalah diagram yang menggambarkan kegiatan atau aktivitas yang terjadi antar aktor dengan sistem. Activity diagram dirancang dengan mengacu pada use case yang telah dirancang sebelumnya. Dengan adanya activity diagram, aktivitas yang dilakukan oleh pengguna dari sistem dapat terlihat dengan jelas. Contohnya, pada aktivitas pembelian in-game currency, pengguna terlebih dahulu harus melakukan login jika sudah punya akun atau register jika belum memiliki akun, jika pengguna melakukan register, maka pengguna harus melakukan verifikasi email terlebih dahulu sebelum akunnya aktif. Setelah sudah berhasil login atau register, selanjutnya pengguna akan masuk ke halaman market. Pada halaman ini, pengguna dapat melihat dan memilih salah satu market yang diinginkan serta memilih jenis order yang diinginkan sesuai dengan kebutuhan, yaitu limit order atau market order. Limit order akan mengeksekusi order sesuai dengan harga yang diinginkan dan sesuai dengan order yang tersedia di market. Apabila harga yang diinginkan tidak terdapat pada order yang tersedia, maka limit order akan secara otomatis membuat order baru di market dengan harga yang diinginkan tersebut. Sedangkan market order akan mengeksekusi order secara langsung berdasarkan order yang tersedia di market sesuai dengan berapa nominal beli yang diinginkan. Dengan menggunakan market order, order akan dieksekusi hingga order yang tersedia atau nominal beli dari pengguna habis. Setelah itu, maka saldo rupiah dari pengguna akan terpotong dan ingame currency akan secara otomatis masuk ke dalam wallet pengguna. Aktivitas pembelian in-game currency ini dapat dilihat pada Gambar 3. 


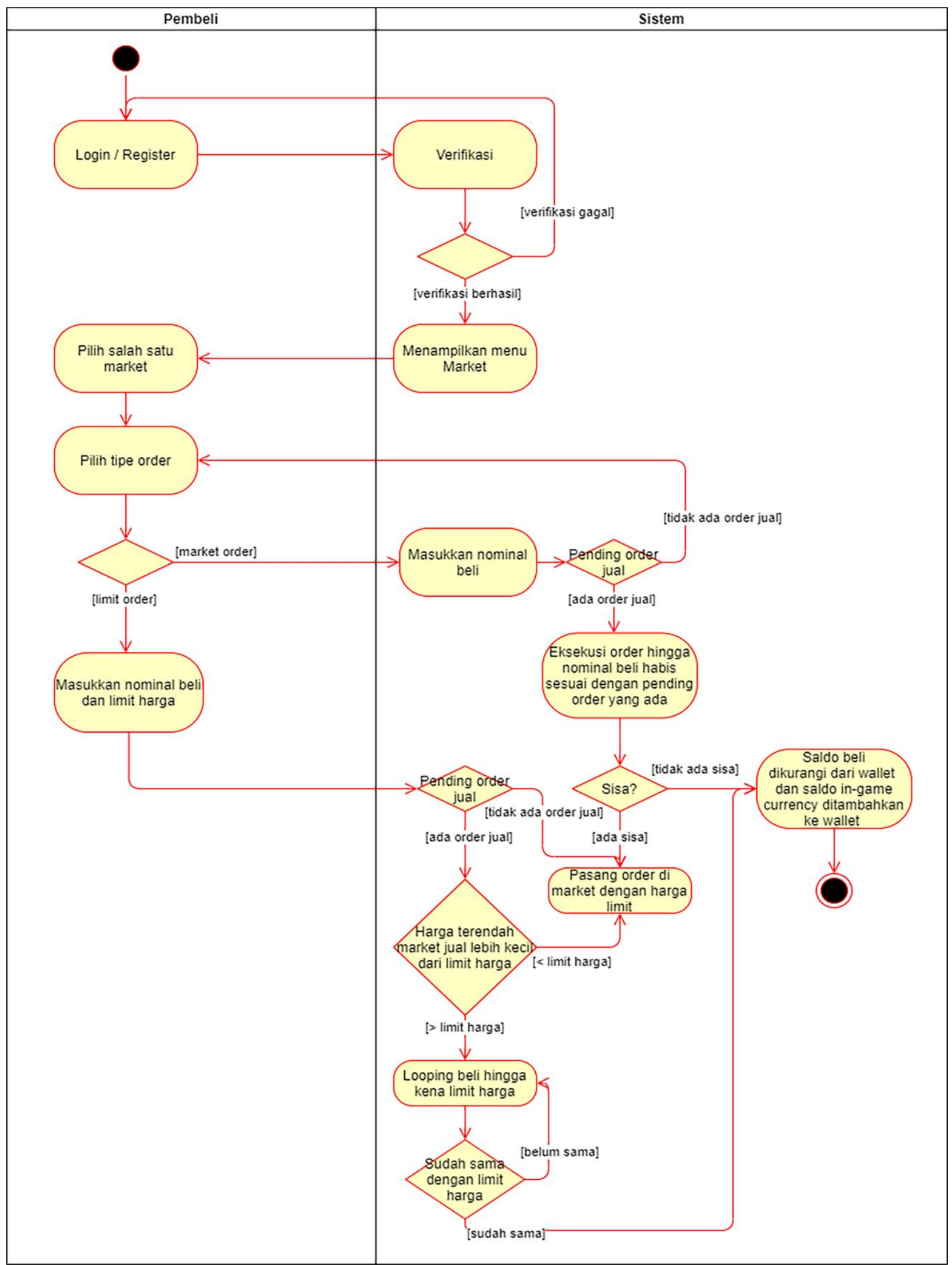

Gambar 3. Activity Diagram Pembelian In-game Currency 
3) Entity Relationship Diagram: Entity relationship diagram menggambarkan struktur database yang akan digunakan pada aplikasi e-marketplace ini. Desain database pada entity relationship diagram dirancang berdasarkan use case dan activity yang dibutuhkan oleh pengguna. Entity relationship diagram ini juga menggambarkan hubungan atau relasi antar tabel di dalam database agar dapat digunakan secara maksimal saat proses pengkodean nantinya. Tabel admins merupakan tabel yang berisi data admin yang akan digunakan oleh admin untuk login ke dalam panel admin. Kemudian, tabel users merupakan tabel yang berisi data pengguna yang sudah mendaftarkan diri ke dalam $e$ marketplace ini. Tabel users juga memiliki relasi one to many ke beberapa tabel, yaitu tabel market_orders, game_deposit_withdraw_information, idr_withdraw_information, game_wallet_transactions, dan idr_wallet_transactions. Relasi one to many dipilih karena satu pengguna dapat memiliki lebih dari satu informasi serta transaksi deposit maupun withdraw in-game currency dan rupiah. Selanjutnya, tabel games berisi data mengenai game yang aset atau in-game currency-nya akan diperdagangkan pada e-marketplace in-game currency ini. Tabel games juga memiliki relasi one to many ke tabel assets yang berisi data in-game currency tersebut. Relasi tersebut dipilih dikarenakan satu game dapat memiliki lebih dari satu in-game currency. Berikutnya, tabel assets juga berelasi one to many ke tabel markets karena satu in-game currency dapat memiliki lebih dari satu market, misalnya market in-game currency A dengan rupiah dan market in-game currency A dengan in-game currency B. Tabel markets berelasi one to many ke tabel market_order_information dan market_orders. Tabel market_order_information adalah tabel yang berisi data mengenai informasi order dari market tertentu. Pada tabel ini terdapat kolom open_price, close_price,low_price, high_price, dan waktu data tersebut disimpan yang akan digunakan untuk keperluan pembentukan grafik nantinya dan akan diperbarui setiap 15 menit secara otomatis. Kemudian, tabel market_orders berisi data order dari pengguna, baik order jual maupun beli dari pengguna. Salah satu kolom dari tabel ini adalah executed_amount, di mana kolom ini berisi nominal jual atau beli yang sudah tereksekusi dan apabila masih belum tereksekusi sepenuhnya, maka order tersebut masih akan berstatus pending. Terdapat juga tabel idr_deposit_methods dan game_deposit_destinations yang berisi data-data yang diperlukan untuk keperluan deposit rupiah maupun in-game currency ke dalam aplikasi e-marketplace ini. Tabel idr_deposit_methods berisi data metode-metode deposit yang dapat digunakan oleh pengguna beserta rekening bank dari e-marketplace ini (jika tidak menggunakan payment gateway) untuk melakukan deposit rupiah. Dan untuk tabel game_deposit_destinations berisi data tujuan deposit dalam game atau akun game untuk deposit yang perlu pengguna kirimkan in-game currency agar deposit in-game currency dapat diproses. Kemudian, pada tabel game_deposit_withdraw_information berisi data game yang dimiliki oleh pengguna untuk melakukan deposit atau withdraw in-game currency. Sedangkan tabel idr_deposit_withdraw_information berisi data bank atau $e$-wallet yang dimiliki oleh pengguna untuk melakukan deposit atau withdraw rupiah. Berikutnya, tabel game_wallet_transactions berisi data deposit maupun withdraw in-game currency yang telah dilakukan oleh pengguna. Dan tabel idr_wallet_transactions tabel yang berisi data deposit maupun withdraw rupiah yang telah dilakukan oleh pengguna. Pada tabel game_wallet_transactions dan idr_wallet_transactions juga terdapat kolom is_internal yang akan terisi apabila deposit atau withdraw yang dilakukan oleh pengguna bersifat internal atau dilakukan di dalam aplikasi $e$ marketplace ini, yaitu deposit atau withdraw antar pengguna. Untuk lebih lengkapnya mengenai gambaran dari struktur database aplikasi e-marketplace ini, dapat dilihat hasil perancangan entity relationship diagram yang ditunjukkan pada Gambar 4. 


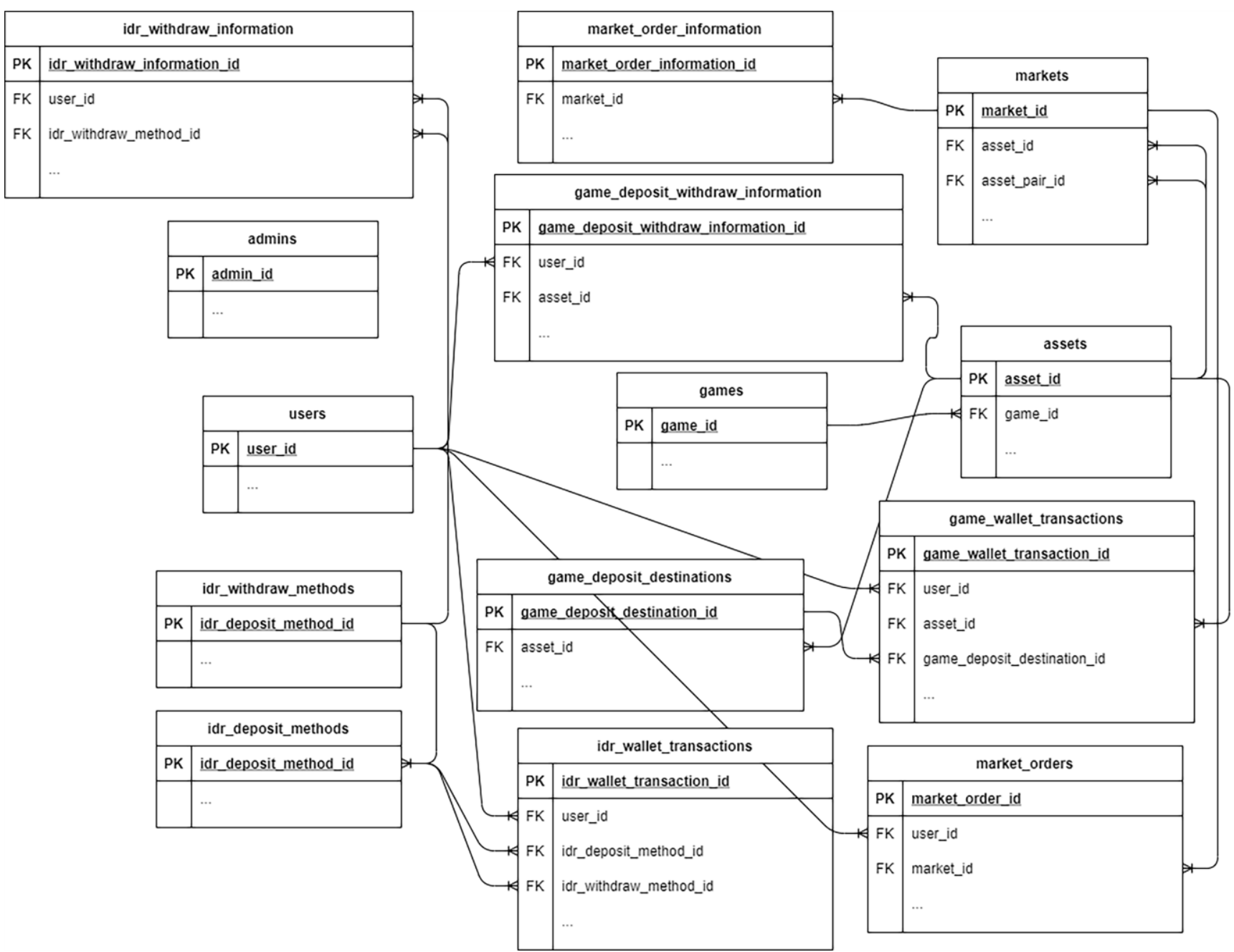

Gambar 4. Entity Relationship Diagram

4) Mockup: Perancangan mockup dilakukan untuk menggambarkan tata letak masing-masing fitur yang ada pada $e$ marketplace ini berdasarkan struktur dan kebutuhan halaman yang ada. Selain itu, mockup ini juga dibuat agar dapat mempermudah dan mempercepat perancangan desain antarmuka dari e-marketplace ini. Berikut adalah beberapa mockup dari beberapa mockup yang telah dirancang, yaitu mockup home, wallet, dan market. Gambar 5 merupakan mockup dari halaman home yang akan tampil ketika pengguna maupun pengunjung pertama kali membuka situs website e-marketplace ini. Terdapat tombol untuk melakukan login atau register serta terdapat juga tombol untuk langsung mengunjungi e-marketplace tanpa melakukan login atau register. Pada bagian bawah, akan ditemukan berbagai informasi singkat mengenai e-marketplace ini, seperti fitur yang tersedia, in-game currency apa saja yang dapat diperjualbelikan, kontak yang dapat dihubungi, dan lainnya. Pada Gambar 6 merupakan mockup dari halaman wallet. Pada halaman ini, pengguna dapat memasukkan beberapa data yang diperlukan untuk melakukan deposit maupun withdraw in-game currency. Sedangkan Gambar 7 merupakan mockup dari halaman market. Pada halaman ini, pengguna dapat melakukan pembelian maupun penjualan in-game currency yang tersedia. Selain itu, terdapat juga fitur grafik dan berbagai data market yang dapat membantu pengguna dalam melakukan transaksi jual beli. 


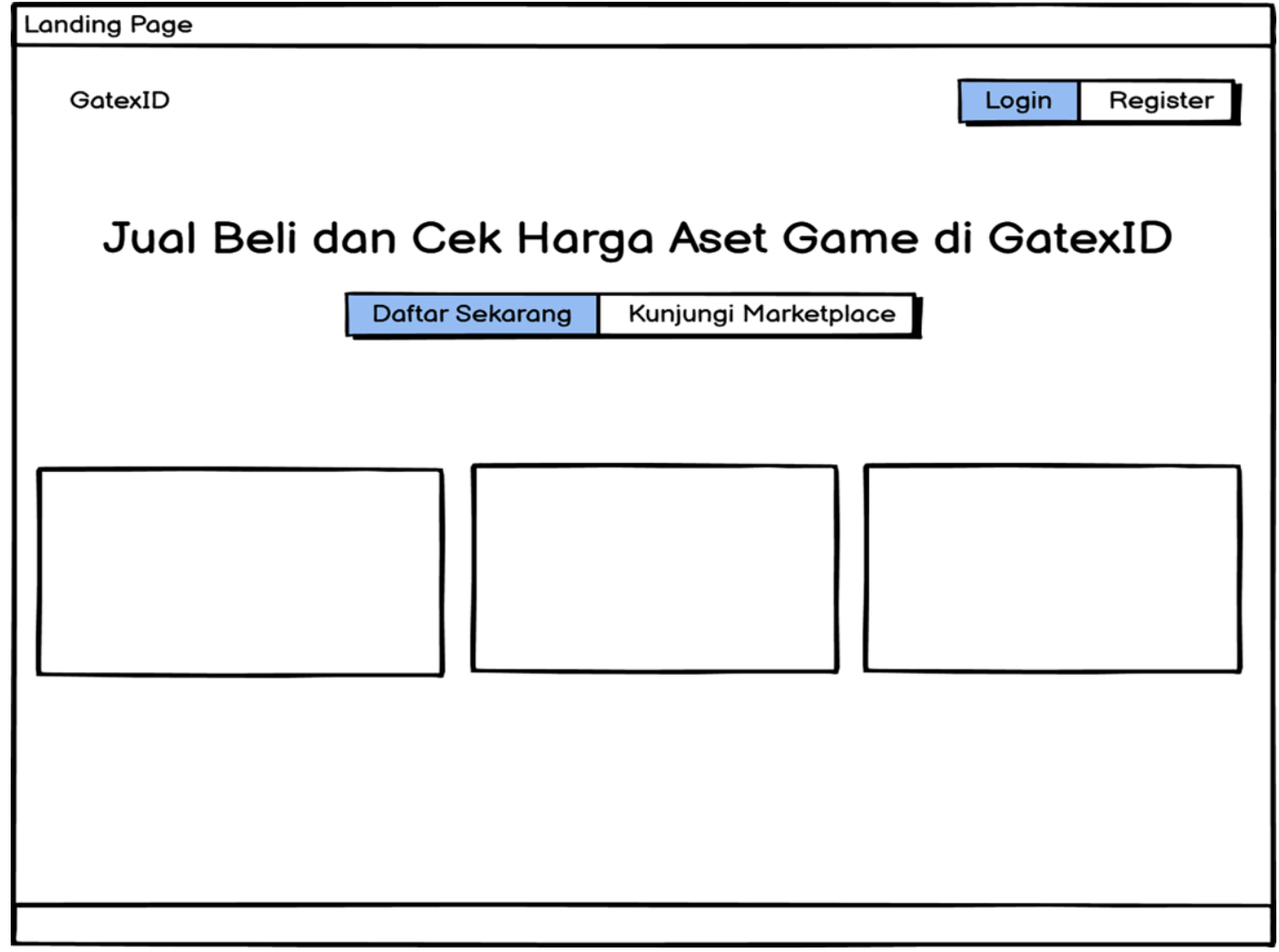

Gambar 5. Mockup Home

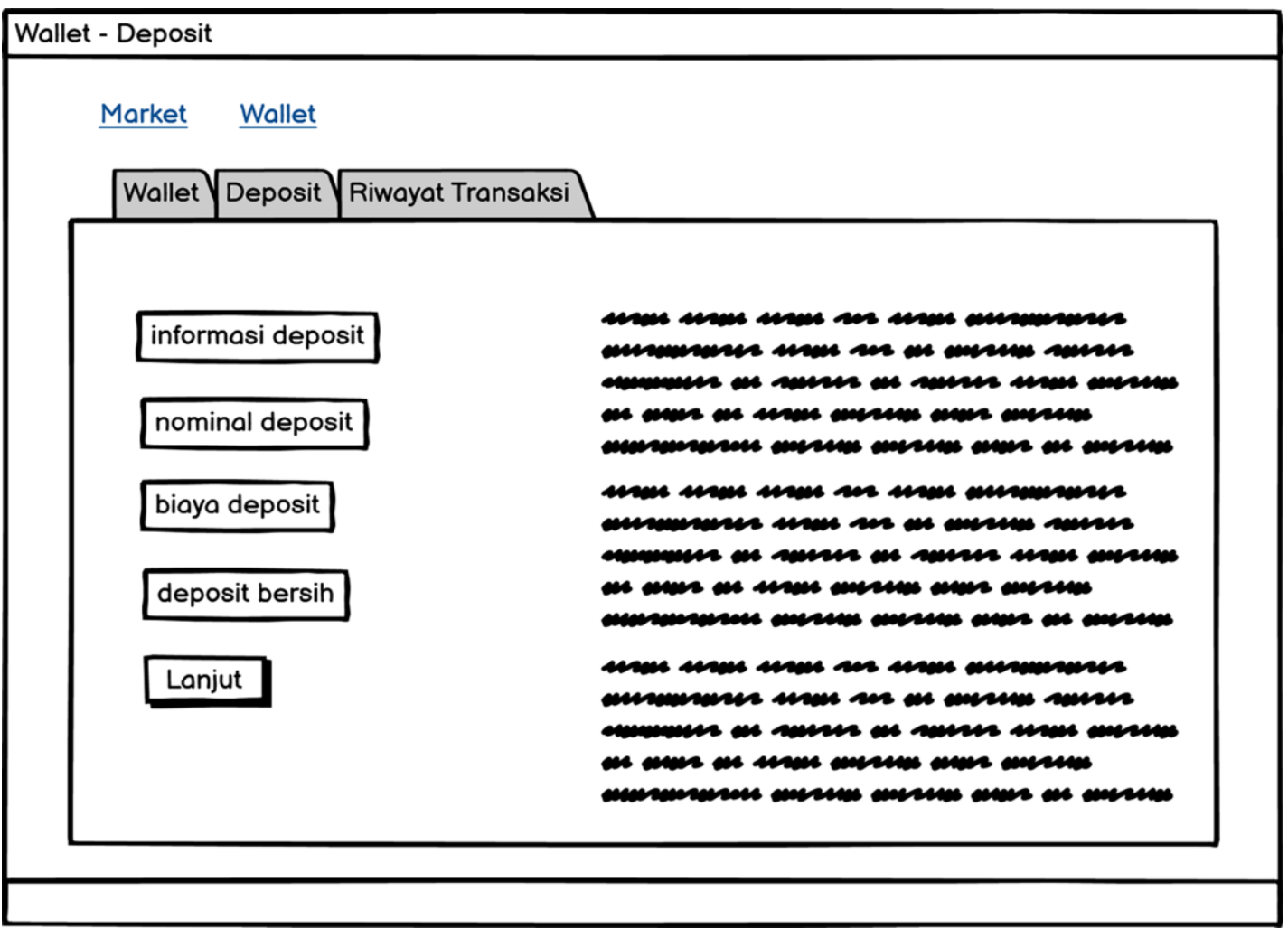

Gambar 6. Mockup Wallet 


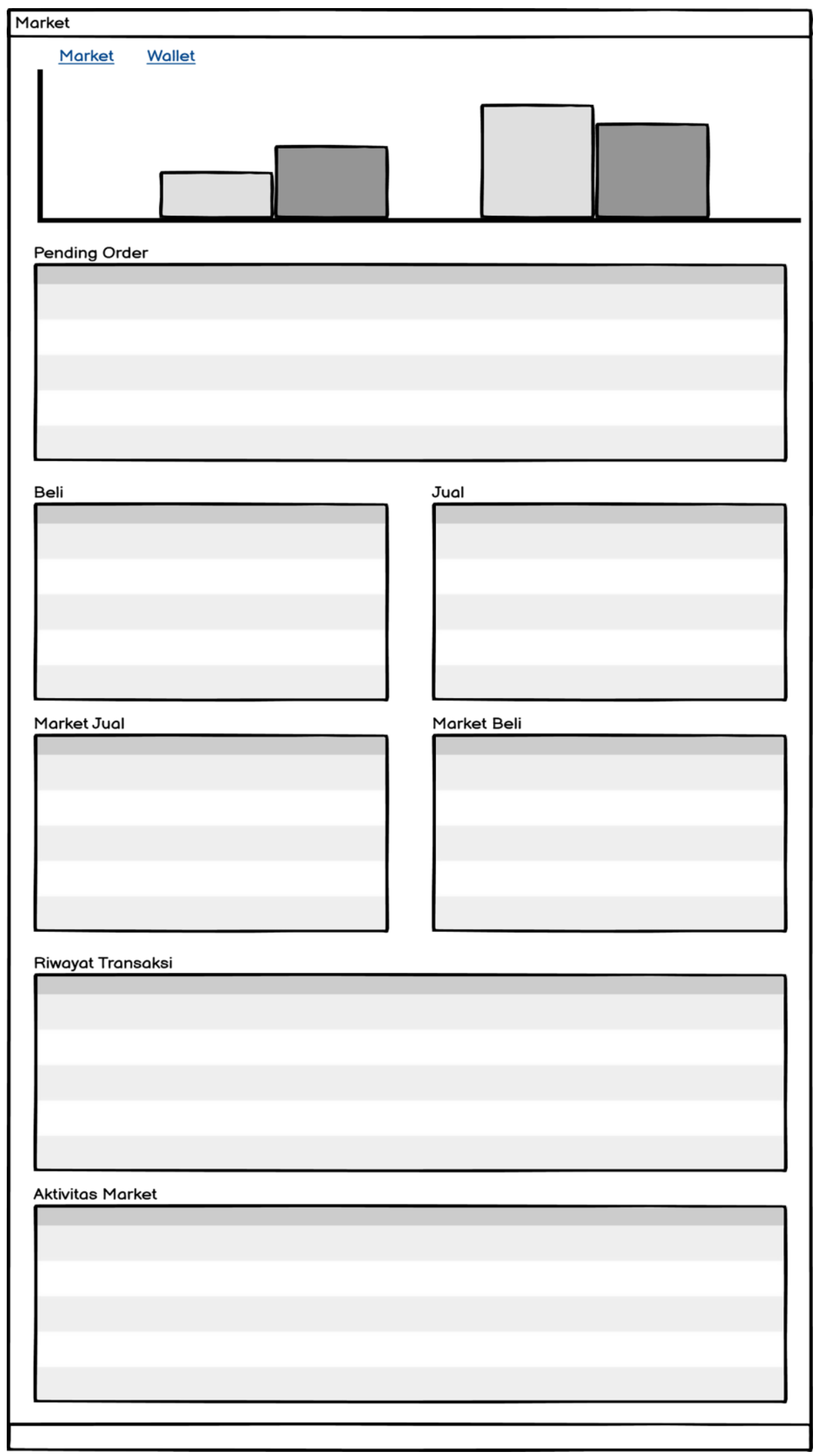

Gambar 7. Mockup Wallet 


\section{Coding}

Selanjutnya, pada tahapan coding, aplikasi e-marketplace ini akan dikembangkan dengan menggunakan framework Laravel. Pengembangan dilakukan dengan mengacu pada desain diagram sistem dan mockup yang telah dirancang pada tahapan sebelumnya. Proses coding dilakukan dengan menggunakan Visual Studio Code dengan Apache yang terintegrasi dengan Laragon sebagai development server-nya. Pada tahapan coding, pair programming digunakan untuk mempercepat proses pengembangan. Pair programming di sini dapat dilakukan dengan menggunakan extension dari Visual Studio Code, yaitu Live Share. Dengan extension ini, proses pair programming dapat dilakukan dan membuat proses pengembangan aplikasi e-marketplace in-game currency ini menjadi jauh lebih mudah dan cepat. Selain itu, pair programming juga dilakukan bersamaan dengan beberapa pengguna, di mana pengguna memberikan saran dan masukan secara langsung mengenai apa yang dibutuhkan dan apa yang tidak, sehingga mempermudah dan mengurangi terjadinya miskomunikasi atau ketidaksesuaian hasil akhir dengan yang dibutuhkan oleh pengguna.

Proses ini dimulai dengan menyiapkan project Laravel baru dengan menggunakan Composer. Setelah itu, dilanjutkan dengan menginstal berbagai package yang dibutuhkan untuk e-marketplace ini. Kemudian, membuat dan menyusun model, migration, route, controller, dan view yang dibutuhkan. Pertama-tama, perlu diinstal beberapa package yang diperlukan. Package yang diinstal akan digunakan untuk menunjang aplikasi e-marketplace ini. Penggunaan package juga dilakukan dengan tujuan agar tidak terlalu lama ketika melakukan pengembangan aplikasi ini. Hal ini sesuai dengan nilai simplicity dari metode Extreme Programming.

Package pertama adalah PHP, yang merupakan bahasa pemrograman dari framework Laravel, sekaligus bahasa pemrograman yang digunakan pada aplikasi ini. Kemudian, fideloper/proxy merupakan package bawaan Laravel untuk mengatur pembuatan tautan yang benar, redirecting, session, dan sejenisnya. Selanjutnya, fruitcake/laravel-cors juga merupakan package bawaan Laravel untuk mengkonfigurasi pengaturan mengenai CORS pada aplikasi ini. Untuk guzzlehttp/guzzle, juga merupakan package bawaan Laravel, yang fungsinya adalah untuk mengirimkan HTTP Request ke luar aplikasi. Kemudian, laravel/fortify merupakan package back-end untuk membangun autentikasi dengan lebih mudah, cepat, dan mudah dikustomisasi dengan berbagai fitur tambahan lainnya. Untuk laravel/framework dan laravel/tinker juga merupakan bawaan Laravel, di mana laravel/framework adalah framework Laravel itu sendiri dan laravel/tinker adalah package untuk dapat menggunakan berbagai code Laravel pada command line, hal ini dapat mempermudah dan mempercepat proses pengembangan apabila membutuhkan data dummy ataupun ingin mengetes coding. Untuk laravel/ui, mirip seperti laravel/fortify, namun laravel/ui di sini hanya digunakan tampilan view untuk autentikasinya saja, namun fungsi autentikasi tetap diatur oleh laravel/fortify. Dan terakhir adalah yajra/laravel-datatables-oracle, yaitu package datatables yang dapat menampilkan data pada tabel dengan lebih ringan, berkat server-side processing yang digunakan, serta memiliki berbagai fitur-fitur yang tidak ada pada tabel biasa. Daftar package yang digunakan ditunjukkan pada Gambar 8 .

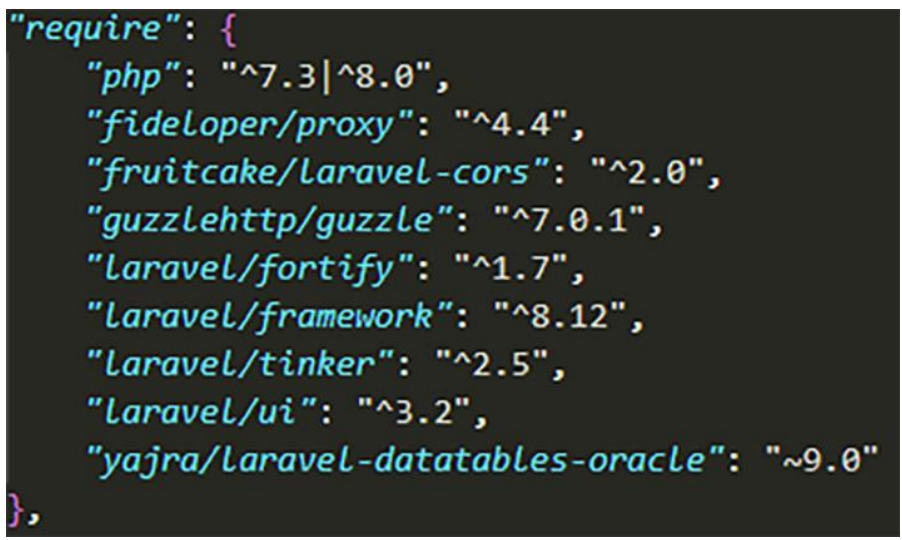

Gambar 8. Daftar Package yang Dibutuhkan

Proses coding e-marketplace ini dilanjutkan dengan membut migration yang diperlukan untuk membuat tabel pada database. Migration dibuat sesuai dengan rancangan entity relationship diagram sebelumnya. Daftar migration yang dibuat dapat dilihat pada Gambar 9. 


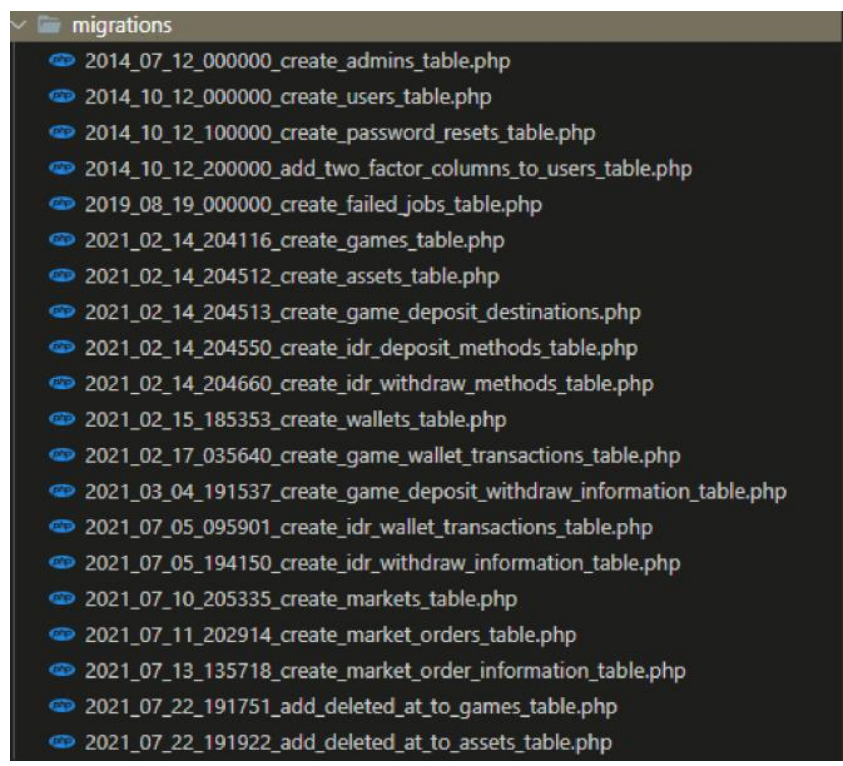

Gambar 9. Daftar Migration

Kemudian, dilanjutkan dengan membuat model yang akan digunakan untuk melakukan koneksi dari aplikasi $e$ marketplace ini ke tabel-tabel yang ada di database. Daftar model dapat dilihat pada Gambar 10.

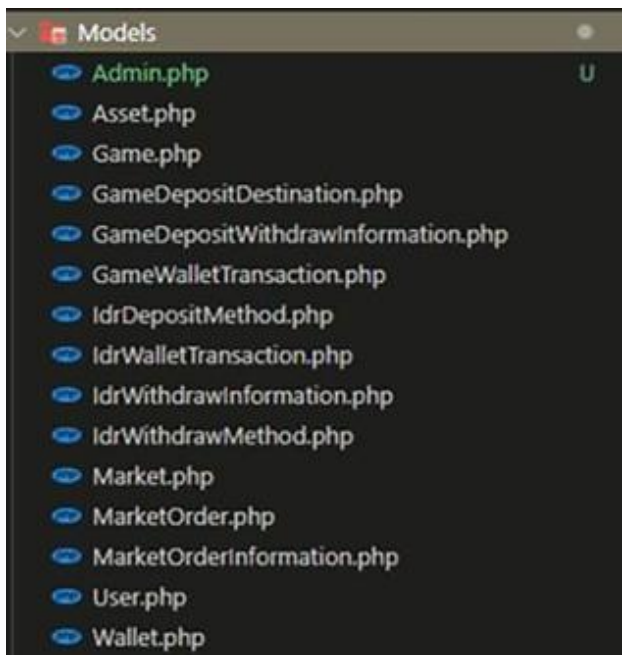

Gambar 10. Daftar Model

Setelah itu, akan dibuat controller dan juga route. Controller akan digunakan untuk meletakkan berbagai logic dari aplikasi ini. Masing-masing controller akan dirancang agar berisi logic sesuai dengan halaman yang ada. Sedangkan route akan digunakan untuk mendefinisikan controller mana yang akan diakses ketika menerima sebuah request dengan URI tertentu. Daftar controller dan route dapat dilihat pada Gambar 11 dan Gambar 12. 


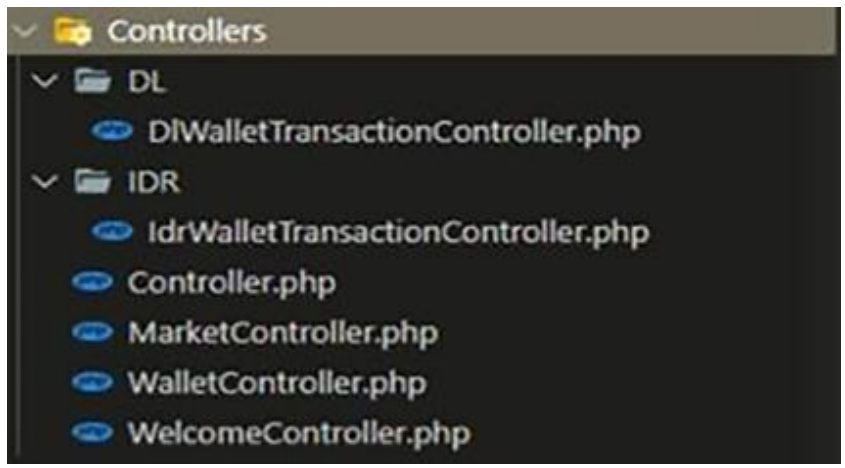

Gambar 11. Daftar Controller

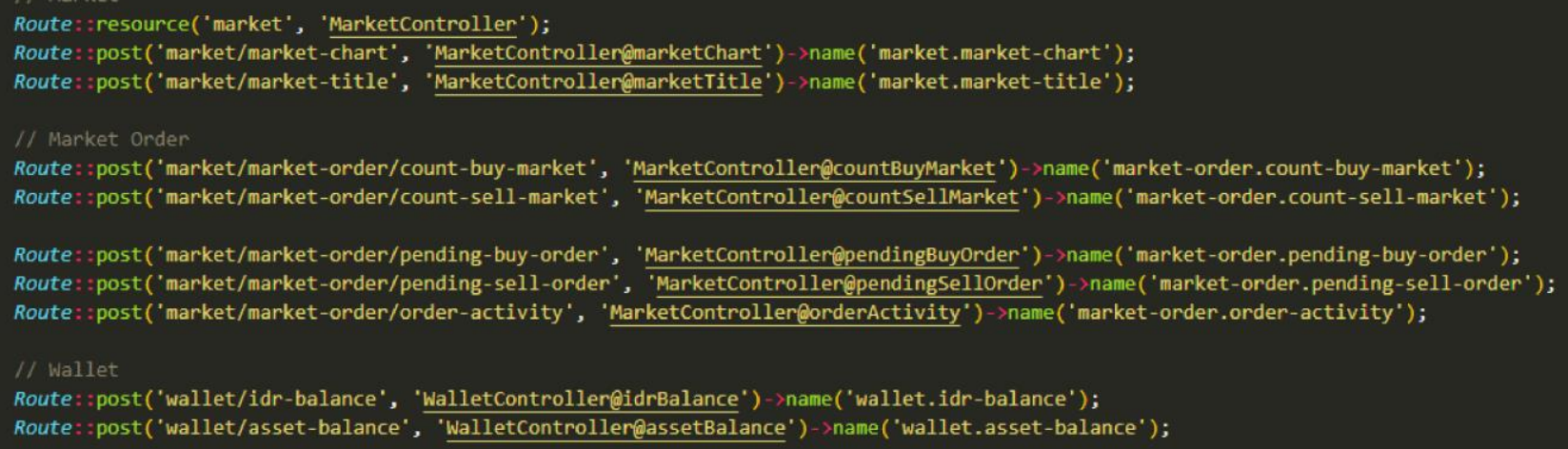

Gambar 12. Daftar Route

Dan terakhir adalah view. View merupakan tampilan dari aplikasi ini, di mana view merupakan bagian yang berinteraksi dengan pengguna dari aplikasi e-marketplace ini. Pada penelitian ini, akan digunakan templating engine dari framework Laravel yang bernama Blade. Templating engine dari Laravel ini memiliki berbagai fitur bantuan yang dapat membantu mempercepat proses implementasi, seperti global helper, Blade's directives, dan masih banyak lagi. Mockup yang telah dirancang sebelumnya akan diimplementasikan ke dalam view Blade. Beberapa hasil implementasi mockup yang telah dirancang sebelumnya ke dalam view Blade dapat dilihat pada Gambar 13, Gambar 15, dan Gambar 16. 


\section{Jual Beli dan Cek Harga Aset Game di GatexID}

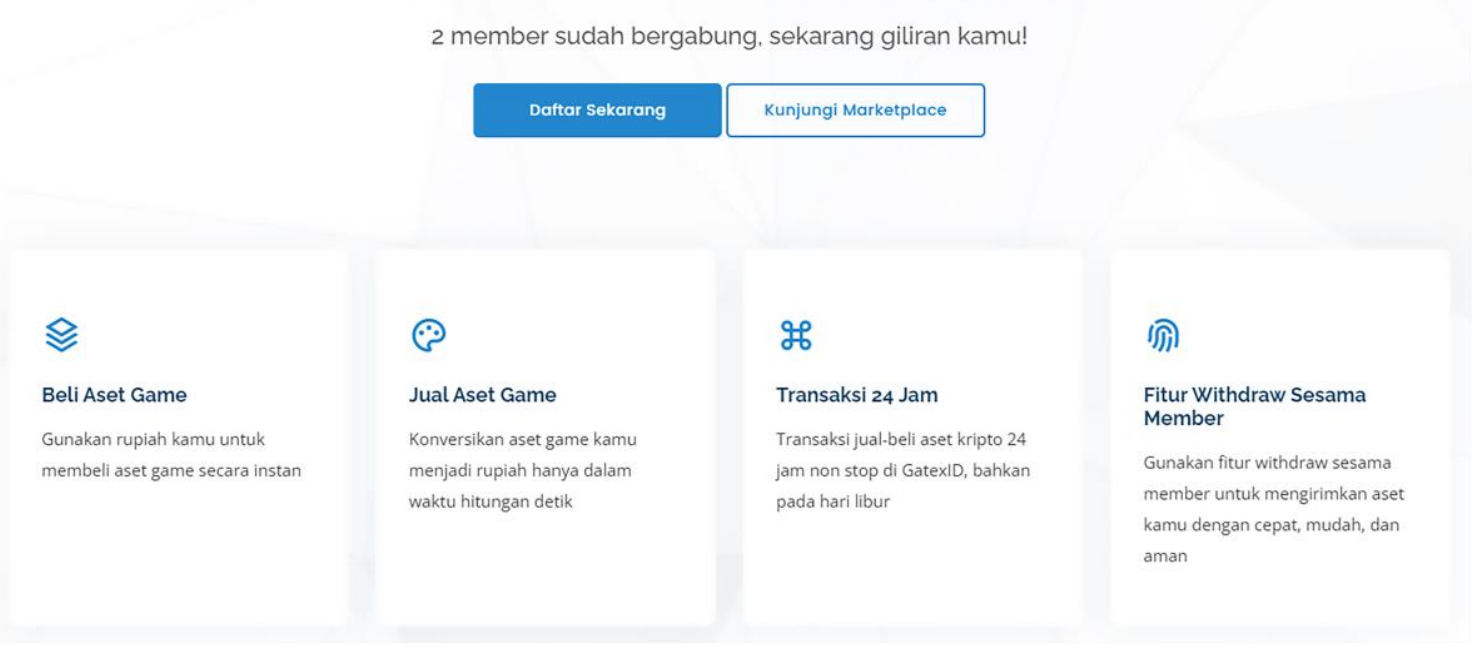

Gambar 13. Tampilan Home

Grafik yang terdapat pada setiap market pada e-marketplace in-game currency ini dibuat berdasarkan harga pembukaan (open price), penutupan (close price), tertinggi (high price), dan terendah (low price) dalam periode waktu tertentu dari sebuah market. Grafik atau chart pada e-marketplace in-game currency ini dibuat dengan menggunakan library yang bernama Apache ECharts.

Apache ECharts merupakan sebuah library JavaScript open-source dan berbasis website yang mendukung visualisasi data dengan cepat dan interaktif. Apache ECharts dikembangkan oleh Baidu Inc. dan diinkubasi serta menjadi salah satu projek open-source dari Apache pada tahun 2018. ECharts awalnya dikembangkan untuk memudahkan pengguna yang tidak terlalu ahli dalam pemrograman untuk tetap dapat memvisualisasikan data dengan mudah dan efisien. ECharts dibangun dengan menggunakan sistem manajemen dan rendering dengan kinerja tinggi dari kanvas HTML5 yang bernama ZRender. Karena hal itu, baik dari sisi performa maupun kustomisasi dari ECharts lebih baik dan lebih mudah dibandingkan library JavaScript untuk visualisasi data lainnya. Perbandingan performa ECharts terhadap beberapa library lainnya dapat dilihat pada Gambar 14 [15].

\begin{tabular}{cccc}
\hline Library & Extended charts & Custom interactions & Canvas \\
\hline HighCharts & $x$ & $x$ & $x$ \\
Chart.js & $x$ & $x$ & $\checkmark$ \\
C3 & $x$ & $x$ & $x$ \\
ECharts & $\checkmark$ & $\checkmark$ & $\checkmark$ \\
\hline
\end{tabular}

Gambar 14. Perbandingan Performa ECharts dengan Library Lainnya [15]

Pada aplikasi e-marketplace in-game currency ini, digunakan salah satu contoh yang disediakan pada website resmi dari Apache ECharts (https://echarts.apache.org/en/index.html), yaitu Shanghai Index pada bagian Candlestick. Shanghai Index ini sangat cocok untuk digunakan pada e-marketplace in-game currency ini, alasannya adalah contoh Shanghai Index yang 
disediakan oleh ECharts memiliki candle hijau dan merah yang menandakan naik atau turunnya harga dari harga sebelumnya. Selain itu, juga terdapat fitur untuk mengatur periode grafik sesuai dengan kebutuhan. Di samping itu, penggunaan grafik Shanghai Index ini hanya membutuhkan open price, close price, high price, dan low price, serta waktu, di mana $e$-marketplace ini sudah didesain untuk mencatat data-data tersebut setiap 15 menit sekali berdasarkan data order yang sudah selesai di market. Selain itu, Shanghai Index dari ECharts ini juga menyediakan fitur MA atau Moving Average yang dapat membantu pengguna yang ingin menjual atau membeli in-game currency dalam membaca pergerakan market.

Moving Average adalah indikator untuk menganalisa kondisi pasar dengan menggunakan harga rata-rata dalam periode tertentu. Indikator ini sering digunakan oleh para trader untuk membaca trend yang telah terjadi, yang akan terjadi, serta yang akan berbalik arah. Shanghai Index yang disediakan ECharts ini menyediakan fitur Moving Average mulai dari MA5, MA10, MA20, dan MA30, serta masih dapat dikustomisasi sesuai kebutuhan. Angka di belakang MA tersebut adalah jumlah candlestick terakhir yang ingin dihitung nilai rata-ratanya.

Pada Gambar 15, dapat dilihat tampilan market serta ECharts yang telah diimplementasikan pada -marketplace in-game currency ini.

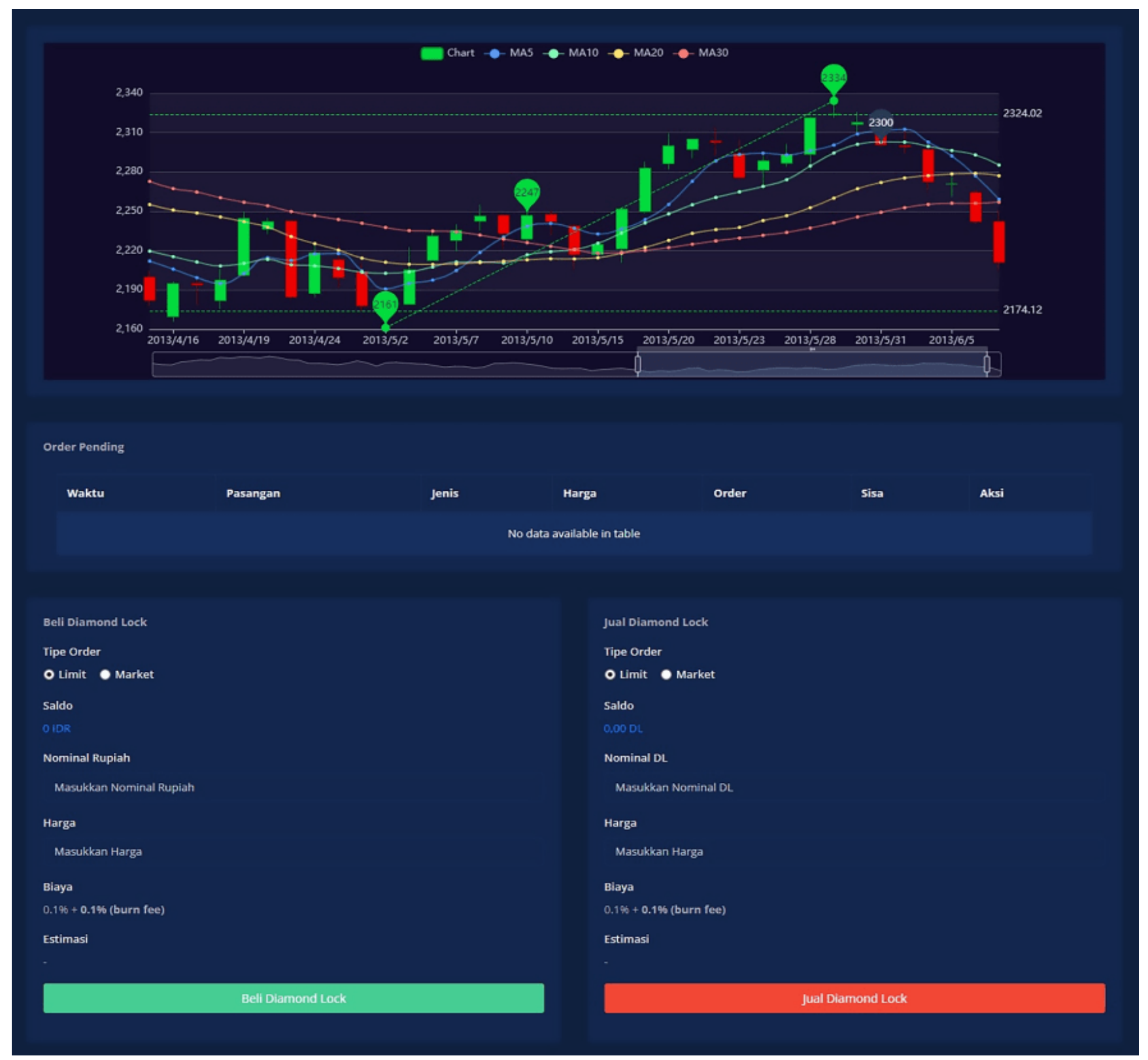

Gambar 15. Tampilan Halaman Market 


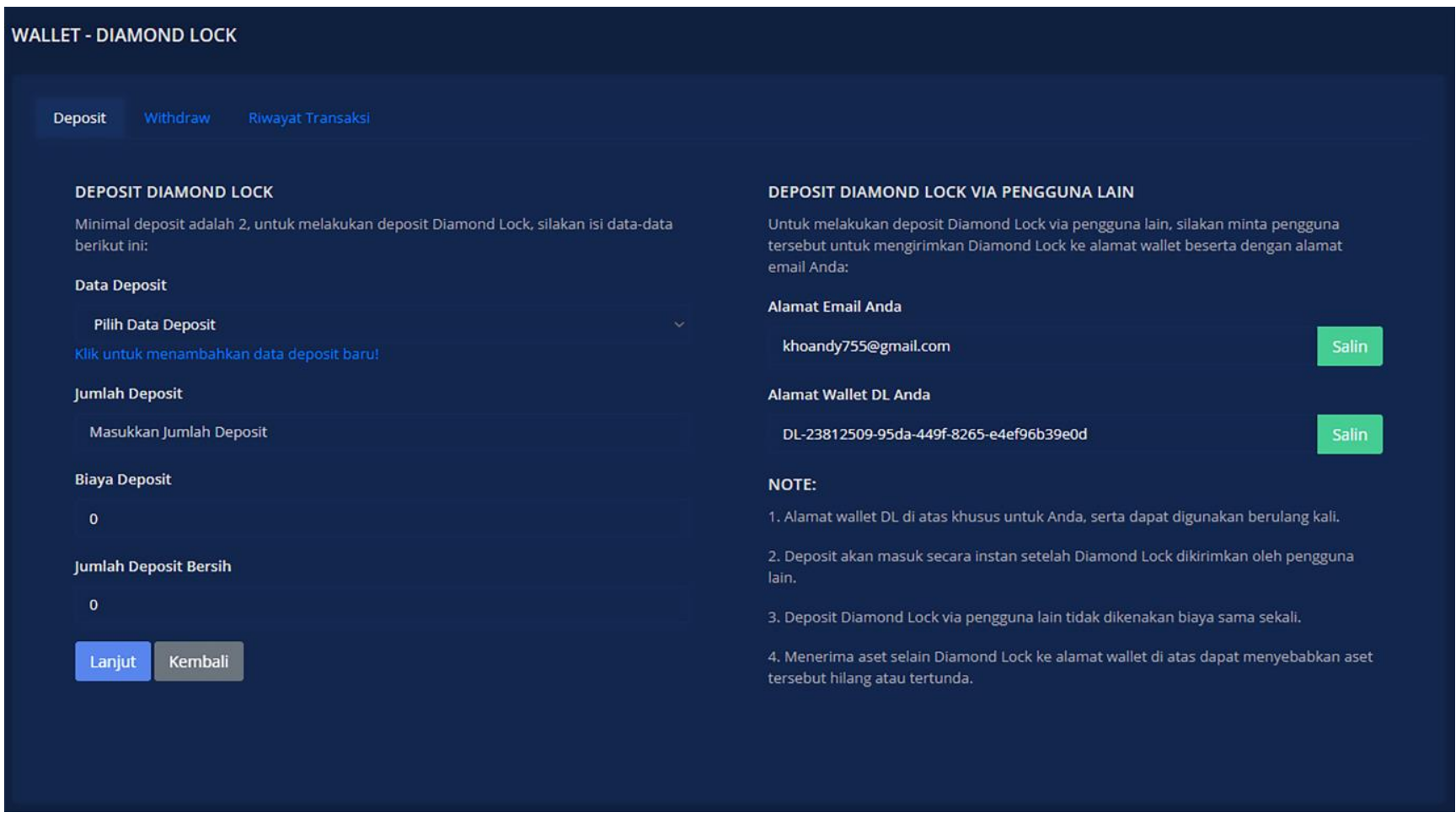

Gambar 16. Tampilan Halaman Wallet

\section{Testing}

Setelah tahapan coding selesai, maka akan dilakukan tahapan testing. Pada tahapan testing, akan dilakukan pengujian sistem dengan menggunakan Black-box Testing dengan metode Equivalence Partitioning. Terdapat empat yaitu penentuan use case, penentuan kriteria, pendefinisian partisi, data uji, kasus uji, pengujian, dan evaluasi hasil pengujian. Pengujian dilakukan oleh kedua pihak, yaitu pengembang dan beberapa pengguna terpilih. Pengujian yang dilakukan menunjukkan hasil yang positif, artinya pengujian yang dilakukan berhasil dan sudah sesuai dengan tujuan dengan berdasarkan pada kasus uji yang telah ditentukan. Pada Tabel 3 ditunjukkan beberapa hasil pengujian yang telah dilakukan.

TABEL3

Hasil PENGUJian

\begin{tabular}{|c|c|c|c|c|}
\hline Kasus Uji & Data Uji & $\begin{array}{l}\text { Tipe } \\
\text { Uji }\end{array}$ & Output & Hasil \\
\hline \multirow[t]{3}{*}{ Registrasi } & $\begin{array}{l}\text { Nama, username, email, nomor } \\
\text { handphone, password, dan konfirmasi } \\
\text { password tidak kosong serta pengguna } \\
\text { belum terdaftar }\end{array}$ & valid & $\begin{array}{l}\text { Tidak ada pesan. Registrasi berhasil dan } \\
\text { langsung diarahkan untuk } \\
\text { memverifikasi email. }\end{array}$ & Berhasil \\
\hline & $\begin{array}{l}\text { Nama, username, email, nomor } \\
\text { handphone, password, atau konfirmasi } \\
\text { password kosong sebagian, kosong semua, } \\
\text { atau tidak sesuai jenis input }\end{array}$ & invalid & $\begin{array}{l}\text { This value is required. This value } \\
\text { should be a valid email. }\end{array}$ & Berhasil \\
\hline & $\begin{array}{l}\text { Username, email, atau nomor handphone } \\
\text { sudah terdaftar }\end{array}$ & invalid & The username has already been taken. & Berhasil \\
\hline \multirow[t]{3}{*}{ Login } & Username atau email dan password benar & valid & $\begin{array}{l}\text { Tidak ada pesan. Login berhasil dan } \\
\text { langsung diarahkan ke daftar market. }\end{array}$ & Berhasil \\
\hline & $\begin{array}{l}\text { Username, email atau password kosong } \\
\text { semua, kosong sebagian, atau tidak sesuai } \\
\text { jenis input }\end{array}$ & invalid & $\begin{array}{l}\text { This value is required. This value } \\
\text { should be a valid email. }\end{array}$ & Berhasil \\
\hline & Username, email atau password salah & invalid & $\begin{array}{l}\text { These credentials do not match our } \\
\text { records. }\end{array}$ & Berhasil \\
\hline
\end{tabular}




\begin{tabular}{|c|c|c|c|c|}
\hline \multirow[t]{8}{*}{$\begin{array}{l}\text { Deposit } \\
\text { In-game } \\
\text { Currency }\end{array}$} & $\begin{array}{l}\text { Data deposit in-game currency dan } \\
\text { nominal deposit in-game currency tidak } \\
\text { kosong }\end{array}$ & valid & Permintaan deposit berhasil dibuat. & Berhasil \\
\hline & $\begin{array}{l}\text { Data deposit in-game currency atau } \\
\text { nominal deposit in-game currency kosong } \\
\text { sebagian, kosong semua, atau tidak sesuai } \\
\text { jenis input }\end{array}$ & invalid & Periksa kembali input-an anda. & Berhasil \\
\hline & $\begin{array}{l}\text { Ketika tombol salin email di klik, email } \\
\text { pengguna akan tersalin }\end{array}$ & valid & $\begin{array}{l}\text { Tidak ada pesan, email akan otomatis } \\
\text { terpilih dan tersalin. }\end{array}$ & Berhasil \\
\hline & $\begin{array}{l}\text { Ketika tombol salin email di klik, email } \\
\text { pengguna tidak tersalin }\end{array}$ & invalid & Tidak ada pesan, email tidak tersalin. & Berhasil \\
\hline & $\begin{array}{l}\text { Ketika tombol buat wallet di klik, alamat } \\
\text { wallet in-game currency milik pengguna } \\
\text { akan dibuat }\end{array}$ & valid & Alamat wallet Anda berhasil dibuat! & Berhasil \\
\hline & $\begin{array}{l}\text { Ketika tombol buat wallet di klik, alamat } \\
\text { wallet in-game currency milik pengguna } \\
\text { tidak terbuat }\end{array}$ & invalid & Terjadi masalah, silakan coba lagi. & Berhasil \\
\hline & $\begin{array}{l}\text { Ketika tombol salin wallet di klik, alamat } \\
\text { wallet in-game currency milik pengguna } \\
\text { akan tersalin }\end{array}$ & valid & $\begin{array}{l}\text { Tidak ada pesan, alamat wallet akan } \\
\text { otomatis terpilih dan tersalin. }\end{array}$ & Berhasil \\
\hline & $\begin{array}{l}\text { Ketika tombol salin wallet di klik, alamat } \\
\text { wallet in-game currency milik pengguna } \\
\text { tidak tersalin }\end{array}$ & invalid & $\begin{array}{l}\text { Tidak ada pesan, alamat wallet tidak } \\
\text { tersalin. }\end{array}$ & Berhasil \\
\hline \multirow{3}{*}{$\begin{array}{l}\text { Membeli } \\
\text { In-game } \\
\text { Currency }\end{array}$} & $\begin{array}{l}\text { Tipe } \text { order, nominal, dan harga tidak tidak } \\
\text { kosong }\end{array}$ & valid & Order beli sukses. & Berhasil \\
\hline & $\begin{array}{l}\text { Tipe } \text { order, nominal, dan harga kosong } \\
\text { sebagian, kosong semua, atau tidak sesuai } \\
\text { jenis input }\end{array}$ & invalid & Periksa kembali input-an Anda. & Berhasil \\
\hline & $\begin{array}{l}\text { Saldo tidak cukup untuk melakukan } \\
\text { pembelian }\end{array}$ & invalid & Nominal tersebut melebihi saldo Anda. & Berhasil \\
\hline
\end{tabular}

\section{SIMPULAN}

Berdasarkan hasil penelitian tentang perancangan dan pengembangan e-marketplace in-game currency menggunakan framework Laravel dengan metode Extreme Programming ini, maka dapat disimpulkan bahwa e-marketplace ini dapat digunakan oleh pelaku transaksi jual beli in-game currency dalam melakukan jual beli in-game currency tertentu dengan mudah dan tentunya lebih aman. Metode Extreme Programming yang digunakan pada perancangan dan pengembangan aplikasi e-marketplace in-game currency ini juga cukup efektif karena dapat mempercepat proses pengembangan dan mengurangi terjadinya ketidaksesuaian kebutuhan pengguna dengan menerapkan metode pair programming dan nilai-nilai Extreme Programming, yaitu simplicity, communication, feedback, courage, dan respect. Hasil dari pengembangan aplikasi e-marketplace in-game currency menggunakan metode Extreme Programming ini juga sudah sesuai dengan kebutuhan pengguna dengan memiliki fitur-fitur penting, seperti fitur grafik pada market dan fitur wallet untuk membantu pengguna dalam mengelola in-game currency yang dimiliki juga sangat membantu. Dengan adanya e-marketplace in-game currency ini, kebutuhan transaksi in-game currency akan menjadi lebih mudah dilakukan, cepat, dan aman. Saran untuk pengembangan aplikasi ini adalah penambahan payment gateway untuk proses deposit dan withdraw rupiah dan juga menggunakan teknologi real-time pada e-marketplace ini untuk meningkatkan kenyamanan dari pengguna.

\section{UCAPAN TERIMA KASIH}

Puji dan syukur kepada Tuhan Yang Maha Esa atas segala rahmat dan karunia-Nya sehingga penelitian ini dapat diselesaikan. Penulisan karya tulis ini tidak terlepas dari bimbingan, bantuan, dan dorongan yang sangat berarti dari berbagai pihak. Oleh karena itu, rasa terima kasih sebesar-besarnya diucapkan kepada dosen pembimbing, teman-teman, dan juga Universitas Internasional Batam atas bantuannya dalam penulisan karya tulis ini.

\section{DAFTAR PUSTAKA}

[1] M. A. Suplig, "Pengaruh Kecanduan Game Online Siswa SMA Kelas X Terhadap Kecerdasan Sosial Sekolah Kristen Swasta Di Makassar," J. Jaffray, vol. 15, no. 2, p. 177, 2017, doi: 10.25278/jj71.v15i2.261.

[2] M. Wang, "Online Games Virtual Products-Transaction and Value," in Proceedings of the 2018 International Conference on Management, Economics, Education and Social Sciences (MEESS 2018), 2018, vol. 236, pp. 340-347, doi: 10.2991/meess-18.2018.63. 
[3] I. Hughes, "Video Game Currency: Clever or Currupting," Itnow, vol. 61, no. 4, pp. 60-63, Dec. 2019, doi: 10.1093/itnow/bwz117.

[4] Channel NewsAsia, "Teenager Arrested in Cheating Case Involving Growtopia Accessories Buyers," www.channelnewsasia.com, 2018. https://www.channelnewsasia.com/news/singapore/teenager-arrested-in-cheating-case-involving-growtopia-9953076 (accessed Oct. 04, 2020).

[5] T. Tristiyanto, Y. Heningtyas, and H. Risnawati, “Aplikasi Marketplace Penyewaan untuk Koperasi Menggunakan Laravel," J. Komputasi, vol. 8, no. 1, pp. 40-49, Apr. 2020, doi: 10.23960/komputasi.v8i1.2536.

[6] E. Yulianto and F. Nurochim, "Pembangunan Marketplace Online Barang Digital Menggunakan Fitur Product Recommendation (Rating \& Tag Analytics) dan Braintree Payment System," Charity, vol. 3, no. 2, pp. 1-13, 2020, doi: 10.25124/charity.v3i2.2712.

[7] S. Susilowati and M. T. Negara, "Implementasi Model Rapid Application Development (RAD) dalam Perancangan Aplikasi e-Marketplace," $J$. TECHNO Nusa Mandiri, vol. 15, no. 1, pp. 25-30, 2018

[8] A. Waworuntu and E. Lumba, "Pengembangan Aplikasi Pembuatan Formulir Digital Menggunakan Laravel," in SEMNATI 2019, 2019 , pp. 16-21.

[9] M. Mansur, R. Yani, and K. Kasmawi, "Desain Sistem Aplikasi Les Privat Menggunakan Pendekatan Extreme Programming,” Digit. Zo. J. Teknol. Inf. dan Komun., vol. 11, no. 1, pp. 30-42, 2020, doi: 10.31849/digitalzone.v11i1.3862.

[10] F. Anwer, S. Aftab, S. Shah Muhammad Shah, and U. Waheed, "Comparative Analysis of Two Popular Agile Process Models: Extreme Programming and Scrum," Int. J. Comput. Sci. Telecommun., vol. 8, no. 2, pp. 1-7, 2017, [Online]. Available: www.ijcst.org.

[11] I. Carolina and A. Supriyatna, "Penerapan Metode Extreme Programming dalam Perancangan Aplikasi Perhitungan Kuota Sks Mengajar Dosen," $J$. IKRA-ITH Inform., vol. 3, no. 1, pp. 106-113, 2019, doi: 10.31227/osf.io/se6f9.

[12] R. S. Pressman and B. R. Maxim, Software Engineering: A Practitioner's Approach, 8th ed. McGraw-Hill Education, 2015.

[13] R. Priskila, "Perancangan Sistem Informasi Persediaan Barang pada Perusahaan Karya Cipta Buana Sentosa Berbasis Web dengan Metode Extreme Programing," J. Comput. Eng. Syst. Sci., vol. 3, no. 2, pp. 94-99, 2018.

[14] G. M. Sari, T. Tristiyanto, and M. Iqbal, "Sistem Informasi Simpan Pinjam Multikoperasi Menggunakan Framework Laravel," J. Komputasi, vol. 7, no. 2, pp. 1-7, 2019, doi: 10.23960/komputasi.v7i2.1902.

[15] D. Li et al., "ECharts: A Declarative Framework for Rapid Construction of Web-based Visualization," Vis. Informatics, vol. 2, no. 2, pp. 136-146, 2018. 